\title{
Hilda Rix Nicholas
}

Hannah Holland, ${ }^{1}$ et al.

\section{Introduction}

Hilda Rix Nicholas (née Rix, later Wright, 1 September 1884- 3 August 1961) [notes 1] $^{1]}$ was an Australian artist. Born in the Victorian city of Ballarat, she studied under a leading Australian Impressionist, Frederick McCubbin, at the National Gallery of Victoria Art School from 1902 to 1905 and was an early member of the Melbourne Society of Women Painters and Sculptors. Following the death of her father in 1907, Rix, her only sibling Elsie and her mother travelled to Europe where she undertook further study, first in London and then Paris. Her teachers during the period included John Hassall, Richard Emil Miller and Théophile Steinlen.

After travelling to Tangier in 1912, Rix held several successful exhibitions of her work, with one drawing, Grande marche, Tanger, purchased by the French government. She was one of the first Australians to paint post-impressionist landscapes, was made a member of the Société des Peintres Orientalistes Français, and had works hung in the Paris Salon in 1911 and 1913. The family evacuated from France to England after the outbreak of World War I. A period of personal tragedy followed, as Rix's sister died in 1914, then her mother in 1915. In 1916 she met and married George Matson Nicholas, only to be widowed the next month when he was killed on the Western Front.

Returning to Australia in 1918, Rix Nicholas once more took up professional painting, and held an exhibition of over a hundred works at Melbourne's Guild Hall. Many sold, including In Picardy, purchased by the National Gallery of Victoria. Following a period painting in rural locations in the early 1920s, Rix Nicholas returned to Europe. A 1925 exhibition in Paris led to the sale of her work In Australia to the Musée du Luxembourg, followed by an extensive tour of her

\footnotetext{
*Author correspondence: hamiltonstone@hotmail.com ORCID: 0000-0002-2516-180X

Licensed under: CC-BY

Received 08-07-2019; accepted 27-11-2019
}

paintings around regional British art galleries. Other exhibitions, such as the International Society of Sculptors, Painters and Gravers, and the Royal Academy of Arts, both in London, soon hosted her work. She was made an Associate of the Sociéte $\mathrm{Na}$ tionale des Beaux-Arts after several of her works were included in its 1926 Spring exhibition in Paris.

In 1926, Rix Nicholas returned to Australia, and in 1928 she married Edgar Wright, whom she had met during her travels in the early 1920s. The couple settled at Delegate, New South Wales; their only child, a son named Rix Wright, was born in 1930. Though she continued to paint significant works including The Summer House and The Fair Musterer, Rix Nicholas, a staunch critic of modernism and disdainful of emerging major artists such as Russell Drysdale and William Dobell, grew out of step with trends in Australian art. Her pictures followed a conservative modern style, portraying an Australian pastoral ideal, and reviews of her exhibitions grew more uneven. She held her last solo show in 1947. Rix Nicholas remained at Delegate until her death in 1961. Her works are held in most major Australian collections, including the Art Gallery of South Australia, Australian War Memorial, National Gallery of Australia, National Gallery of Victoria, and the Queensland Art Gallery.

\section{Early Life}

Henry Finch Rix and Elizabeth Sutton, each of whom had migrated to Australia as children with their families, met and married in Victoria in 1876. They had two daughters, Elsie Bertha, born in 1877, and Emily Hilda (known ubiquitously just as Hilda), born in Ballarat on 1 September $1884 .{ }^{[2][3]}$ The Rix children grew up in a gifted and energetic family. Henry, a mathematics teacher, was appointed a district Inspector of Schools in the 1880s; he was also a poet who wrote in support of Australian Federation, and played Australian rules football for the Carlton Football Club. ${ }^{[4][5]}$ Elizabeth had grown up assisting in her parents' thriving music business in Ballarat, and was a 
singer who performed with the Ballarat Harmonic Society. ${ }^{[5]}$ In addition, she had a studio in Melbourne's Flinders Street, and a committee member of the Austral Salon, "a meeting place for intellectual women interested in the fine arts." ${ }^{[4]}$ She painted in an academic style, generally choosing still lifes and flowers as subjects, though she painted some large landscapes in the Beechworth region. ${ }^{[6]}$

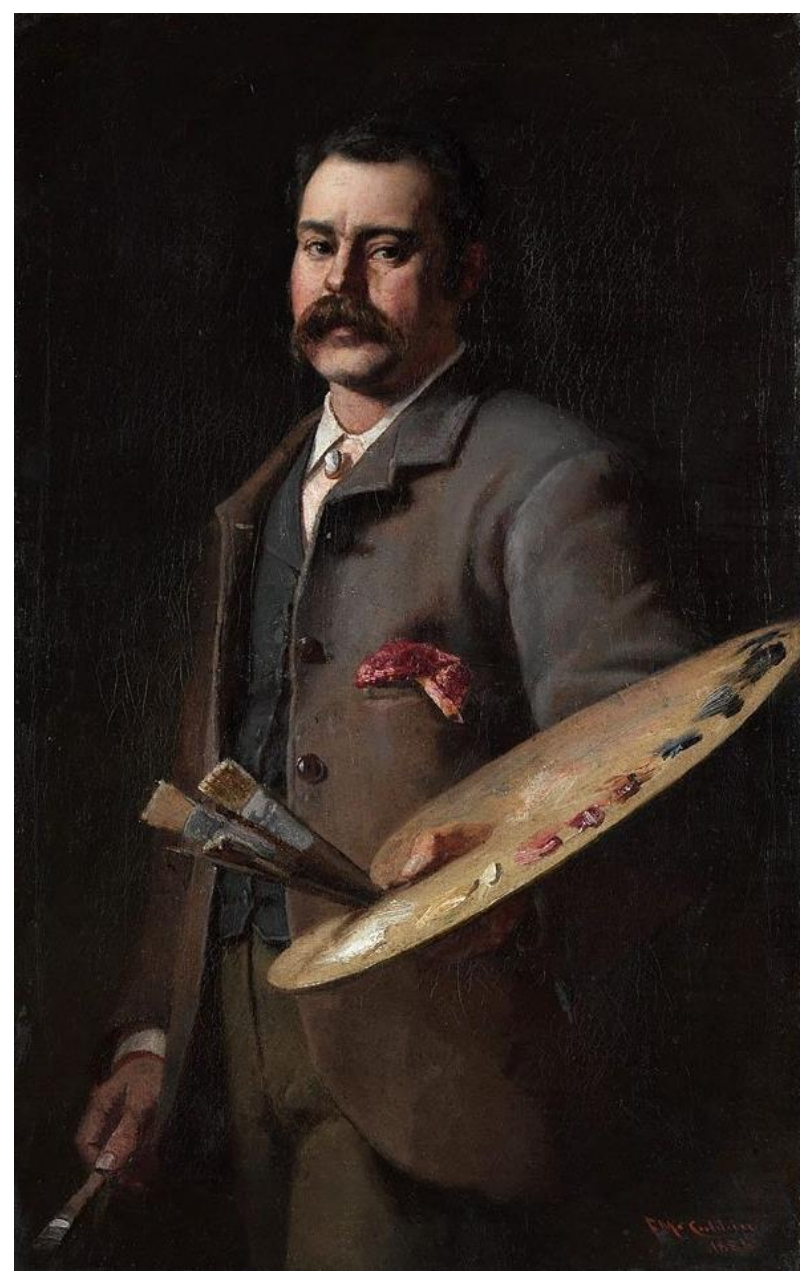

Self-portrait of Frederick McCubbin, member of the Heidelberg School and Rix Nicholas's first major influence

Hilda Rix and her sister Elsie both played musical instruments as children, performing songs and dances at regional shows. ${ }^{[4]}$ Elsie was a singer and actor who performed at the meetings of the Austral Salon, and the sisters collaborated in designing posters for the Salons. ${ }^{[7]}$ As a child, Hilda was enthusiastic about drawing. ${ }^{[4]}$ Her artistic efforts drew praise while she was attending high school at Melbourne Girls Grammar (known as Merton Hall), ${ }^{[1]}$ though in most other respects Rix was not an outstanding student. Both took art lessons with a Mr Mather, before Hilda studied at the National
Gallery of Victoria Art School from 1902 to 1905 , where she was taught by a leading Australian Impressionist, Frederick McCubbin. Her fellow students were mostly women and included Jessie Traill, Norah Gurdon, Ruth Sutherland, Dora Wilson, and Vida Lahey. ${ }^{[8]}$ Rix would subsequently be critical of McCubbin's approach to teaching, referring to his methods as "vague persuasions". Nevertheless, the author of the only comprehensive biography of Rix, John Pigot, considered that McCubbin influenced her in several ways: he emphasised the creativity of individuals rather than imitating the style of any one school of painting; he modelled the importance of nationalistic ideas and subjects that would become so prominent in her later painting; and his work emphasised the painting's subject over technical considerations. ${ }^{[9]}$

Drawings undertaken by Rix while she was still a student were included in annual exhibitions at the Victorian Artists' Society and the Austral Salon. At the same time, she was working as a professional illustrator for textbooks and a periodical, the School Paper, published by the Victorian Department of Education. ${ }^{[9]}$ In 1903, all of the Rix family women had works included in the Austral Salon's exhibition. ${ }^{[10]}$

One of Rix's early sketchbooks survives and pages from it were reproduced in the 2012 book, In Search of Beauty. Although she described the works as her "very earliest drawings when a child in Melbourne", the dated pages indicate they were created up until at least the age of twenty. They mostly portray women, and the settings and dress of her subjects reflect the relatively affluent and educated milieu of which the Rix family were part. ${ }^{[1]}$

In this period, it was common for aspiring Australian artists to seek further training in Europe, particularly London and Paris. Henry Rix arranged to take his family there in conjunction with a trip he was making to study British education reforms, purchasing first-class tickets to travel in 1906. ${ }^{[12[13]}$ But Henry, who had been overworked and ill, died suddenly, and for a time it appeared the trip might not happen. Denied a widow's pension (Henry had been 58: too young for his wife to be eligible), the family had to reorganise their affairs and work out if they could afford to get to Europe. ${ }^{[9[14]}$ Finally, by combining an inheritance, rental income from their home, and money raised through the sale of works by both mother and daughter, they were able to trade the 
first class tickets for second class berths, and they set sail for England early in 1907..$^{[14[15]}$

\section{Europe 1907-1912}

Just before her departure from Australia, Rix was advised by the painter Arthur Streeton to study with many different masters, as a means of preserving her own originality. Her subsequent career reflected that advice. ${ }^{[16]}$ One of her first teachers was John Hassall, although he had initially protested that she was already a better drawer than himself. Rix thought him "simply great", and Pigot credits Hassall's simple and direct style with influencing the artist's later practice. $^{[17]}$

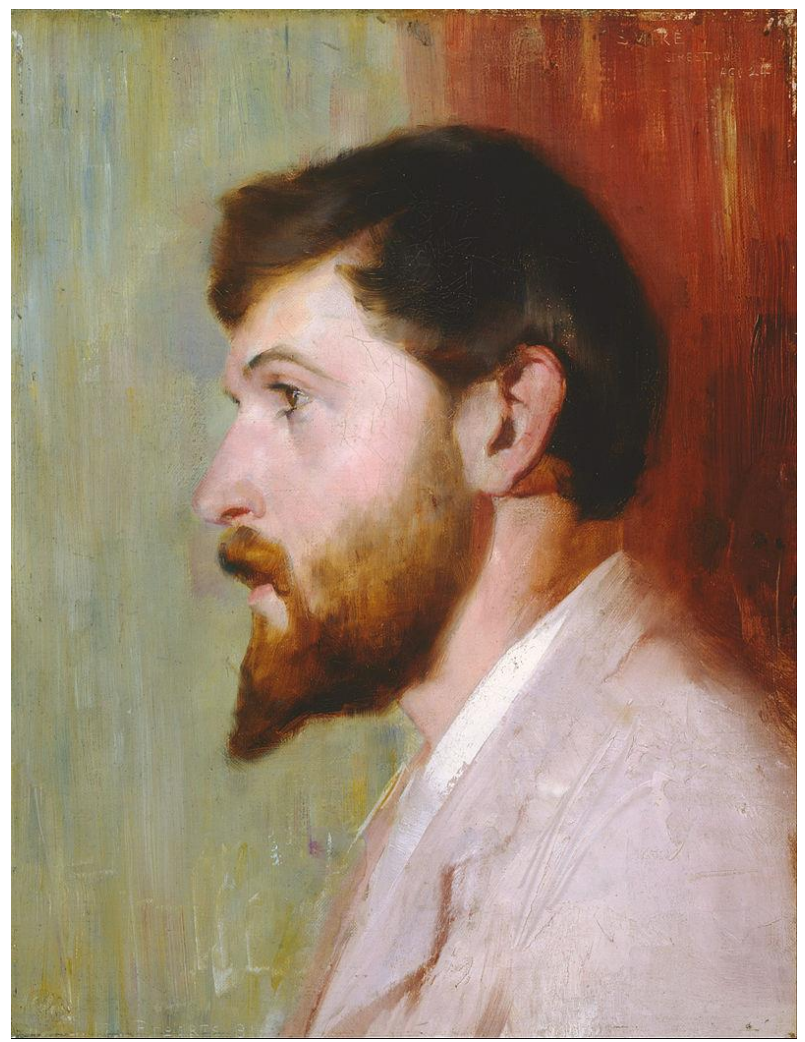

Arthur Streeton, as painted by Tom Roberts. Rix followed his advice to study under many different teachers.

Late in 1907, Rix moved with her sister and mother to Paris, where they lived in Montparnasse. ${ }^{[18]}$ There she met with Australian artist E. Phillips Fox, went on sketching expeditions to the Jardin du Luxembourg where Ethel Carrick Fox worked, and became a student at the Académie Delécluse, operated by academic painter Auguste Delécluse. ${ }^{[19][20]}$ She found his guidance in life drawing enormously valuable, though she thought his approach to colour "too drab". ${ }^{[18]}$ The following year she was taught by American impressionist Richard Emil Miller. From him she acquired the use of a relatively bright colour palette, not always naturalistic, as well as his dextrous technique; she did not, however, follow his predilection for pretty compositions, favouring more direct and clear images ${ }^{[21]}$ Continuing to acquire skills from a wide range of artists, she next studied at the Académie de la Grande Chaumière, including with Swiss-born illustrator Théophile Steinlen. ${ }^{[2]}$

Rix, her sister and mother, spent summers traveling together. In 1908 they journeyed through France and Italy, and later at the artists' colony at the fishing village of Étaples, in northern France..$^{[23][24]}$ Among the artists active there was Frenchman Jules Adler, who took an interest in Rix's work, as well as many Australians, including Rupert Bunny, James Peter Quinn, Edward Officer and one of the colony's longest-term residents, Iso Rae. ${ }^{[25 \mid[26]}$

Around 1909, Hilda Rix met Wim Brat, $\left.{ }^{[n o t e s} 2\right]$ an architecture student from a wealthy Dutch family. He asked Rix's mother for approval to marry her daughter, and Mrs Rix agreed. A initial engagement turned sour, however, when Rix spent time at her fiancé's home, where she found her prospective husband dominated by his mother, who strongly disapproved of the match. Rix reluctantly broke off the engagement. ${ }^{[28][29]}$

Rix continued to work, and was rewarded with hangings at the Paris Salon in 1911, alongside fellow Australians Arthur Streeton and George Bell. ${ }^{[30]}$ She took up study at Académie Colarossi at the time Henri Matisse was painting from the academy's models and offering an open studio to its students. ${ }^{[31]}$ At this time she became only the second Australian to have a work acquired by the French government, and is considered by Australian curator Elena Taylor to be, after the established expatriates Bunny and Phillips Fox, "without doubt the most successful of the Australian artists in France". ${ }^{32]}$

\section{Moroccan Paintings 1912-1914}

Many women artists visited and worked in north Africa in the late nineteenth and early twentieth centuries; ${ }^{\left[{ }^{[3]}\right.}$ Rix twice visited the region, resulting in some of her most significant artistic development and works. She first joined American painter Henry Ossawa Tanner, his wife and a Miss Simpson on a trip to Morocco in January 1912. They travelled via Spain, where Rix viewed the work of Velázquez, whose compositions and palette she greatly ad- 
mired. ${ }^{[34]}$ The party's destination was Tangier, a place where many other artists had sought inspiration. Jean-Joseph Benjamin-Constant lived and painted there in the 1870s, while John Singer Sargent visited in the 1880s. ${ }^{\text {[notes }}{ }^{3]}$ Henri Matisse also visited Tangier in $1912^{[37]}$ and, like Rix, travelled to Tétouan, about 60 kilometres $(37 \mathrm{mi}$ ) east of Tangier; $^{[38]}$ they used the same models. ${ }^{[39[40]}$

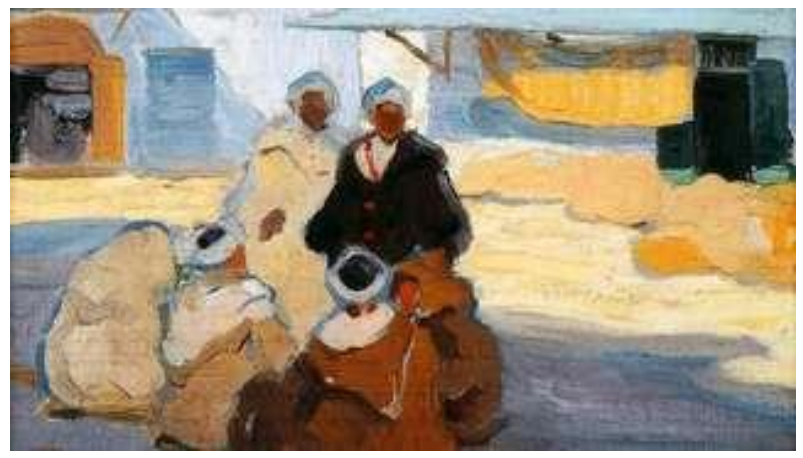

Detail of Men in the Market Place, Tangier (1914), showing a typical subject of Rix Nicholas's Moroccan work, and her post-impressionist style adopted during this period.

For about three months, Rix sketched and painted in Tangier, spending time in the open-air market place or soko. Her enthusiasm for the place was evident from her correspondence:

Picture me in this market-place - I spend nearly every day there for it fascinates me completely - have done 16 drawings and two oil things so far-Am feeling thoroughly at home now so am going to take out my big oil box - wanted to get used to people and things first - Oh how I do love it all! ... Oh the sun is shining I must out to work. ${ }^{[41]}$

Morocco had a similar effect on Rix as it did on many artists who visited. Paintings were created in highkeyed colours that captured the intense north African light, and most works focussed on the figures, dress and activity of the people, or the local architecture. ${ }^{[42]}$ One interpretation of the perspective of Rix is that she was an orientalist, in the sense used by academic Edward Said. Pigot, in his exhibition essay Capturing the Orient, considered how Rix's works "emphasise the exoticism" of the locations she portrays.

Representing the Orient through the objective depiction of costumes and dress maintained the counterfeit truthfulness of orientalist imagery, concealing the reality of oriental life and the violence that underscored the colonial project. In Rix Nicholas's imagery costumes embodied the exoticism of the East and signified its sense of cultural 'otherness'. ${ }^{43]}$

4 of 13 | WikiJournal of Humanities
On the other hand, Hoorn argues that Rix and her sister were to a significant extent counter-orientalist: they focussed on the common nature of human experience rather than cultural expressions of difference ${ }^{[44]}$ and they sought to portray everyday life in Tangier as they found it, rather than presenting generalised views of the orient. ${ }^{[45]} \mathrm{Her}$ works similarly reflect a modernist approach to the empirical: in using the bright light of north Africa to help bring out the structures and shapes that made up visual impressions. ${ }^{[4]}$ Hoorn wrote:

She did not seek out or embellish her pictures with the "orientalist" stereotypes that she had learned while growing up in Melbourne...In her writing and painting, she actively campaigned against what she saw as the fakery of "orientalism". Her pastel drawings and oils strive to present an accurate account of the dress, manners and appearance of her subjects. ${ }^{[47]}$

Stylistically, Rix's Moroccan paintings have been characterised as the "most abstract, flat and postimpressionistic of her career". ${ }^{[48]}$ Rix Nicholas's approach may have been influenced by Matisse: they stayed in the same hotel in Tangier at the same time for nearly two months, travelled to Tétouan during the same week, and may be in a photograph together taken during that trip. ${ }^{[38][49]}$

She was one of the first Australians to paint postimpressionist landscapes, including Men in the Market Place, Tangier (1914) and View of Tangier (1914), produced during a second visit to the city. ${ }^{[50]}$ They demonstrate the development of her style at the time: loose brush strokes, a palette confined to a few low-keyed colours, and an emphasis on shadow and light, affecting both the overall impression made by the picture and the treatment of individual figures. ${ }^{[51]}$

The 1912 trip represented a landmark in her work, led to several exhibitions and her first significant international critical acclaim. The journeys are the subject of one of the few books about the artist's work, Jeanette Hoorn's Hilda Rix Nicholas and Elsie Rix's Moroccan Idyll: Art and Orientalism. ${ }^{\left[{ }^{[2]}\right.}$ Exhibition of her first works produced immediate results: the French government purchased one of her pictures of the market in Tangier, ${ }^{[53]}$ and in 1913 she again had paintings displayed at the Paris Salon. ${ }^{[54]}$ The purchase by the French government was of a pastel drawing, Grande marche, Tanger, ${ }^{\text {[notes }}{ }^{4]}$ which she would later copy in oils. The drawing was favourably discussed in the French edition of the New York Herald, but not by one The Sydney Morning Herald reviewer, who complained that "the drawing and colour are eccentric, after the post-impressionist manner" and described 
the central figure as "grotesque in its want of finish". [55][56]

The Herald's reviewer was at odds with prevailing sentiment. Her success was widely reported in Australian papers such as Hobart's Mercury, Melbourne's Argus and Adelaide's Register. ${ }^{[57]}$ In addition to displaying the results of her trip at the Salon, she was invited to exhibit in 1913 and 1914 at the Société des Peintres Orientalistes Français, also in Paris. ${ }^{[58]}$ Rix was made a member of the society. ${ }^{[59]}$ In November 1912, there was a solo exhibition at a private gallery, Galerie J Chaine and Simonson. Her work was illustrated in the Notre Gazette, reflecting her emerging status as a significant artist, ${ }^{[60]}$ and the French press reported her exhibitions. ${ }^{[61][62]}$

She returned to Tangier again in early 1914, this time with her sister Elsie, who also drew and wrote but whose main purpose was to provide her sister with company, assistance and protection from curious onlookers while she painted. ${ }^{[63]}$ Rix painted regularly at the soko, where she would both attract much attention and sometimes disrupt the flow of traffic as she sketched. ${ }^{[64]}$ The sisters returned to England and then to France, where Rix again spent the summer at Étaples, until the outbreak of World War I resulted in evacuation to London in August. ${ }^{[65]}$

\section{Disaster 1914-1918}

Her retreat to London began a tragic period in her life. Rix's mother Elizabeth had been unwell, and deteriorated during the crossing from France to England. Elizabeth was brought to hospital when they landed; though she partially recovered and was moved to a nursing home, her other daughter, Elsie, fell ill with typhoid. ${ }^{[66][67]}$

Rix moved between her two ailing family members until, on 2 September 1914, Elsie died. For three months she withheld the news from her mother, fearing it would harm her already fragile condition. Elizabeth survived the news, but as the war continued, Rix's artistic output dwindled almost to nothing. Then in March 1916, Elizabeth died. ${ }^{[68]}$ Rix was just over thirty years old, and all her immediate relatives were now dead. Recalling the experience, she later wrote: "I could scarcely put one foot in front of the other and walked like an old thing". [68]

Further misfortune arrived when in France, an Australian officer, Captain George Matson Nicholas, ${ }^{\text {[notes 5] }}{ }^{5 a s}$ posted to Étaples. He heard about the female Australian artist who had to leave her paintings behind when she and her family left abruptly for England. Nicholas sought her works and admired them, and decided to contact the artist when next he was on leave. He met Rix in September 1916, and they were married on 7 October at St Saviour's, Warwick Avenue in London. After three days together, he returned to duty; she was widowed five weeks later on 14 November, when he was shot and killed during battle at Flers, on the Western Front. ${ }^{[70][71][72]}$ Initially writing in her diary that she had lost the will to live, Rix Nicholas's grief eventually found its expression in three paintings, titled And Those Who Would Have Been Their Sons, They Gave Their Immortality (a phrase from a poem by Rupert Brooke), Desolation and Pro Humanitate. The second of these paintings (which was destroyed by fire in 1930), portrayed a gaunt and tearful woman shrouded in a black cloak, crouched staring at the viewer amidst a battlescarred landscape, featureless but for the crosses on distant graves. The National Gallery of Australia holds a charcoal drawing made as a study for the work. ${ }^{[73]}$ Desolation was "a portrait of a woman cradling a ghostly child". The reviewer for the Sydney Morning Herald wrote of the painting:

Desolation is almost gruesome in the grim delineation of the figure typifying all the widowed world in one lone woman. There she sits, lost in an awful reverie, over the stricken battlefield. The work is an epitome of wasteful ruin. ${ }^{[74]}$

Her triptych Pro Humanitate conveys the tragedy of her short marriage to Nicholas, ${ }^{[75]}$ but like Desolation, it was destroyed in a fire. The work comprised panels representing a happy couple in an outdoor vista; the moment of death of a soldier, arms outstretched in a crucifixion pose; and the grieving widow, watched by the ghost of the soldier. ${ }^{[76]}$ In visualising "the ruin caused by war", ${ }^{[7]}$ her works were more personal than those of other artists of the last years of World War I, such as Paul Nash and Eric Kennington, and her representation of widowhood was both unusual for its time, and confronting for the viewer. ${ }^{[78]}$

\section{Return to Australia, 1918-1923}

In March 1918, Rix Nicholas, along with her brother-inlaw Athol Nicholas, left England and arrived in Melbourne on 10 May. There, with the encouragement of artist Henrietta Gulliver and the members of the city's Women's Art Club, Rix Nicholas began to reconstruct her career as a professional artist. ${ }^{[79]}$ It did not take long. In November, she was amongst the members of the Club whose works were displayed at the Athaeneum Hall, where a critic described her as the "dominating personality of the show". ${ }^{[80]}$ At the same 
time, in Melbourne's Guild Hall she held a large exhibition of her European and north African paintings, sketches and drawings, with over a hundred works on display. Several were sold, including In Picardy, purchased by the National Gallery of Victoria. [81][notes ${ }^{6]}$ Noting the artist's success in Paris and London, the reviewer for The Argus admired her "appreciation of character and talents for observation and representation" ${ }^{\left[{ }^{[7]}\right.}$ while The Age was struck by "the influence of modern French Impressionism in [her paintings'] fearless handling of sunlight and open air effects. "[83] When the exhibition travelled to Sydney in 1919, reviews were likewise positive both from newspapers and from her peers such as Julian Ashton, Antonio Dattilo Rubbo and Grace Cossington Smith. ${ }^{[83]}$ The Sydney show also resulted in the purchase of several of her works by the Art Gallery of New South Wales. ${ }^{[84]}$

In 1919, Rix Nicholas moved to Sydney and settled in Mosman, where she made new friends and produced a range of landscapes and outdoor portraits, often continuing her post-impressionist style. ${ }^{[85]}$ The artist experienced further success in her exhibitions and with regular favourable reviews in the press, such as for her show in the Queen Victoria Markets in September $1920 .{ }^{[86]}$ Nevertheless, Pigot has argued that her place in the Australian art world at the time was complex, and her style was affected by vigorous debate around the emergence of modernism, which was being resisted by local critics. ${ }^{[87]}$ Her experience of this more conservative Australia, and the effects of the deaths of all those close to her, contributed to Rix Nicholas abandoning her more experimental art, and returning to more academic and figurative subjects. ${ }^{[88]}$ This ultimately had a detrimental effect on the long-term trajectory of her career. Pigot argues that her refusal to conform to the gendered expectations of the Australian artistic establishment led to her rejection. ${ }^{[89]}$

In 1922, a competition was launched by the trustees of the Melbourne Public Library for a mural to commemorate the Great War. Rix Nicholas learned of the competition and quickly prepared and submitted an entry. Three judges, all respected Melbourne academic artists, submitted a report to the trustees, who met to consider the entries received. The trustees voted six to five to grant the commission to Harold Septimus Power, despite the fact that he had not fulfilled the conditions of entry; they then withheld the judges' report from publication, decided not to exhibit any of the competition entries, and delayed awarding any prize. One newspaper reported that Rix Nicholas's entry had been one of the top three. Rix Nicholas was furious, as were some former soldiers who wrote letters to newspapers about the incident. Pigot suggests that gender was a factor: "While Rix Nicholas's claim to be a war artist was legitimate, the fact that she was a woman meant that she was denied an equal place within the discourse". ${ }^{[90]}$

The Australian War Memorial was building a collection of art commemorating the war around the time Rix Nicholas offered her triptych Pro Humanitate. But it was rejected; the acquisitions described it as 'of too intimate a character for inclusion in a public collection'. ${ }^{[11]}$ The Memorial eventually decided to purchase one of her works portraying a French woman (titled $A$ Mother of France (1914)), but not the other work offered, which depicted an Australian soldier ( $A$ Man (1921). According to Pigot, this reflected the gendered approach taken by institutions, which considered that subjects suitable for portrayal by artists were dependent upon their sex. ${ }^{[92]}$ It may have further been influenced by the Memorial's strategy for collection development, which at that time emphasised acquisition of portraits of senior officers. ${ }^{\left[{ }^{[3]}\right.}$ Whatever the view of competition or acquisition committees, her works were "popular with the soldiers themselves, and in this way they actively shaped the image of the digger". ${ }^{[94]}$

Her paintings of war subjects were just one aspect of Rix Nicholas's developing commitment to nationalist ideals and the heroic representation of Australia. ${ }^{[95]}$ At the time of her 1919 exhibition, Rix Nicholas had commented that she wished "to show the people [of Europe] what is possessed in a land of beauty where the colour scheme is so different, and which sent so many gallant men to the struggle for liberty". ${ }^{[82]}$ In this respect she was following in the tradition of the Australian Impressionists and writers such as Henry Lawson and Banjo Paterson, who extolled the virtues of the bush and pioneer life. Accompanied by her friend Dorothy Richmond, Rix Nicholas set out to paint in rural New South Wales, beginning in Delegate, a small town on the border of New South Wales and Victoria. Here she created numerous works, including In Australia, His Land, and The Shearers. ${ }^{[96]}$ Other works from this period include The Three Sisters, Blve Mountains(1921-22), which is in the collection of the National Gallery of Australia. ${ }^{[2]}$ While Australian patriotic imagery and discourse of the period was very male-dominated, Rix Nicholas's portraits were frequently of women, such as in The Monaro Pioneer, The Magpie's Song and Motherhood..$^{[97]}$

Back in Sydney, Rix Nicholas held another solo exhibition in August 1923. Once again it was favourably reviewed, and there was again the description of her work in masculine terms: the reviewer at Sydney's Sunday Times described her as "the most virile, 
and, in many respects, the strongest woman painter Australia has yet produced". ${ }^{98][84]}$ Rix Nicholas disliked being thought of as a "woman" artist, but she took such reviews as complimentary, given how dismissive were critics in general when considering paintings by women. ${ }^{[99]}$

\section{Second trip to Europe, 1924-26}

In 1924, Rix Nicholas, again travelling with Dorothy Richmond, set sail for France, intending to exhibit her works in Europe. She voyaged on the Ormonde, which was also carrying the Australian Olympic team. She befriended several of the team members and painted a portrait of one for an Olympic artists' competition. ${ }^{[100][\text { notes } 7]}$

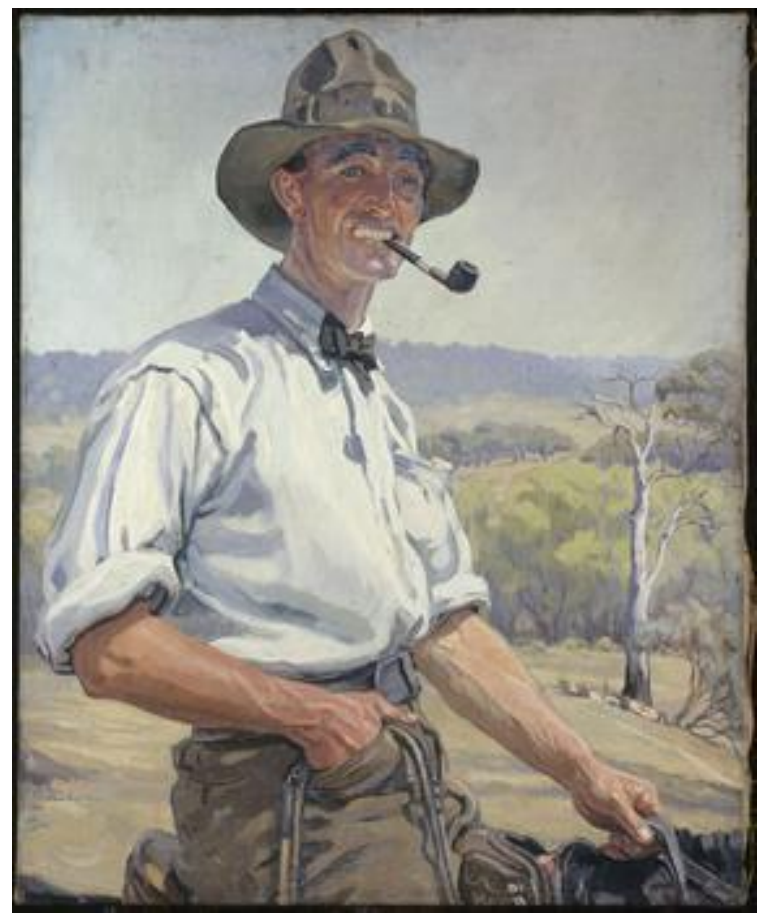

In Australia, painted by Rix Nicholas while staying at Delegate, New South Wales in 1922 or 1923.

Arriving in Paris in June, eventually Rix Nicholas rented a studio in Montparnasse, which had previously belonged to French artist Rosa Bonheur. ${ }^{[101]}$ An exhibition at the "prestigious" Georges Petit Galerie in Paris in January 1925 was a great success. It led to important sales, including to the Musée du Luxembourg, making her the only Australian woman to have more than one work in its collection ${ }^{[102]}$ and, according to one report, one of only three Australian artists represented at all at that time, the others being Rupert Bunny and Arthur Streeton. ${ }^{[103]}$ The exhibition led to a tour of her works to London and British regional galleries, the first time any Australian artist had archived such prominence; ${ }^{[104]}$ between 1926 and 1928, her works were shown in Hull, Sunderland, Tyne and Wear, Bootle, Blackpool, Northampton, Warringto n, Folkestone, Leicester, Derby, Gateshead and L eek in Staffordshire. ${ }^{[105]}$

The work purchased by the Luxembourg in 1925 was In Australia, a portrait of Ned Wright, manager of the property at Delegate where she had stayed in the early 1920s. He is portrayed on horseback, a pipe clasped in his exposed and bright teeth, with a panoramic backdrop of an Australian pastoral landscape. His stance is casual, self-assured and heroic, consistent with the upbeat nationalism of Australia at the time. ${ }^{[106][107]}$

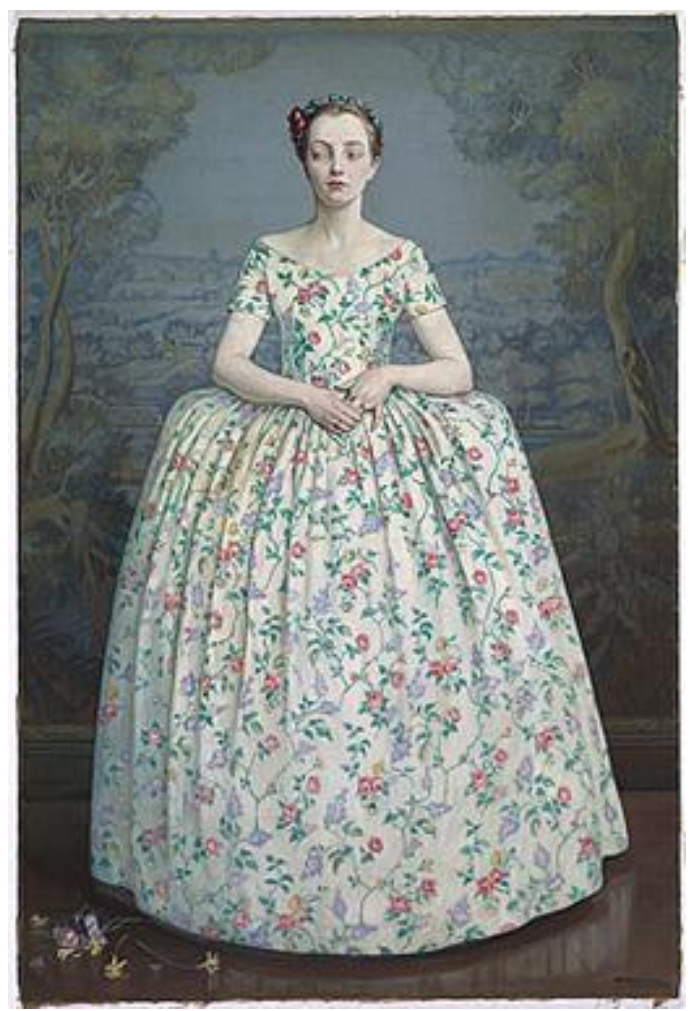

Les fleurs dédaignées (1925)

1925 saw further exhibitions, including at the International Society of Sculptors, Painters and Gravers, and the Royal Academy of Art, both in London. ${ }^{[08]}$ A solo exhibition that December at the Beaux Arts Gallery, London, displayed His Land, which was described as having "the rare quality of conveying the spirit of life in the Commonwealth as well as portraying that life pictorially ... the whole picture seems to convey the sunny heat-laden atmosphere of Australia". ${ }^{[109]}$ Like In Australia, this work suggests the elemental strength and vitality that Rix Nicholas advocated should pervade Australian painting. ${ }^{[96]}$

That year, Rix Nicholas created one of her most extraordinary and largest works. Standing almost 2 metres $(6.6 \mathrm{ft})$ high, and 128 centimetres $(4.20 \mathrm{ft})$ 
wide, Les fleurs dédaignées ('The despised flowers') is an "unnerving"[110] and "arresting"[1111] portrait of a young woman in fashionable eighteenth-century clothing. Painted not with the artist's typical technique, but in a mannerist style, the subject faces the viewer yet is glancing away, her pose tense, expression unreadable, with a bunch of discarded flowers on the ground next to the hem of her enormous formal dress. ${ }^{[110][111]}$ Although portraying a young lady, the person chosen to sit was "a Parisian professional model and a prostitute, apparently with a reputation for being moody and cantankerous". ${ }^{[111]}$ The pastiche created in this work is striking: a sixteenth-century artistic style, a composition comprising a seventeenth-century tapestry and an eighteenth-century dress, created by a twentieth-century artist. It certainly reflected the scope of Rix Nicholas's abilities and ambitions, and was painted with the specific intention of having it hung at the Paris Salon. ${ }^{[111]}$ When the work was displayed in Sydney in 1927, it grabbed The Sydney Morning Herald critic's attention:

For combination of grace, dramatic strength, and clearness in technique this picture would be difficult to surpass. There is nothing finicky about it; it tells its story with vivid directness... The artist has brought out with revealing strokes an expression of vindictive malice which is for the moment resting there; and the hands, the fingers of one grasped tightly by the other, give a clear indication of nervous tension within. The treatment of flesh tones and the general arrangement, drawing attention gently but not too obtrusively to the columbines scattered on the polished floor-those are excellent. ${ }^{[112]}$

While she exhibited many of the Australian works completed before arriving in France, she was also creating many new works, including illustrations and portraits of traditional life and costume, produced during a summer in Brittany. ${ }^{[113]}$ In 1926, Rix Nicholas was again included in London's Royal Academy of Art exhibition, where one of her Brittany paintings, Le Bigouden, was hung. ${ }^{[108]}$ She appeared at the Société Nationale des Beaux-Arts Spring exhibition in Paris, ${ }^{[114]}$ in which she had eight works, a very large number for a single artist. ${ }^{[115]}$ The Société not only hung many of her paintings and drawings: she was elected an Associate to the organisation in that year. ${ }^{[16]}$

At the end of 1926, Rix Nicholas and Dorothy Richmond returned together to Australia. Energised by her success, Rix Nicholas purchased a car, filled its rear compartment with painting equipment, and the pair set out to paint the landscape, ranging from Canberra and the Monaro plains to the south, up into central Queensland. ${ }^{[177][118]}$ During a publicity-attracting occasion, she painted figures on the beach at Bondi, which was reported by various publications including Australian magazine, The Home. ${ }^{[119][120]}$

\section{Wright and Knockalong, 1928-61}

Rix Nicholas had met the farming family, the Wrights, in the early 1920s, including Ned, the subject of In Australia. After returning to the district, she married Edgar Wright on 2 June 1928 in Melbourne, and the couple settled on a property called Knockalong, near Delegate. ${ }^{[121]}$ She continued to exhibit under the name Rix Nicholas. Her friend Dorothy Richmond, with whom she had visited the region at the start of the decade, married Edgar Wright's cousin, Walter, and settled in the same region. ${ }^{[122]}$ Then, in 1930, Rix Nicholas and her husband had their only child, a son, whom they named Rix. ${ }^{[122][\text { [notes 8] }}$

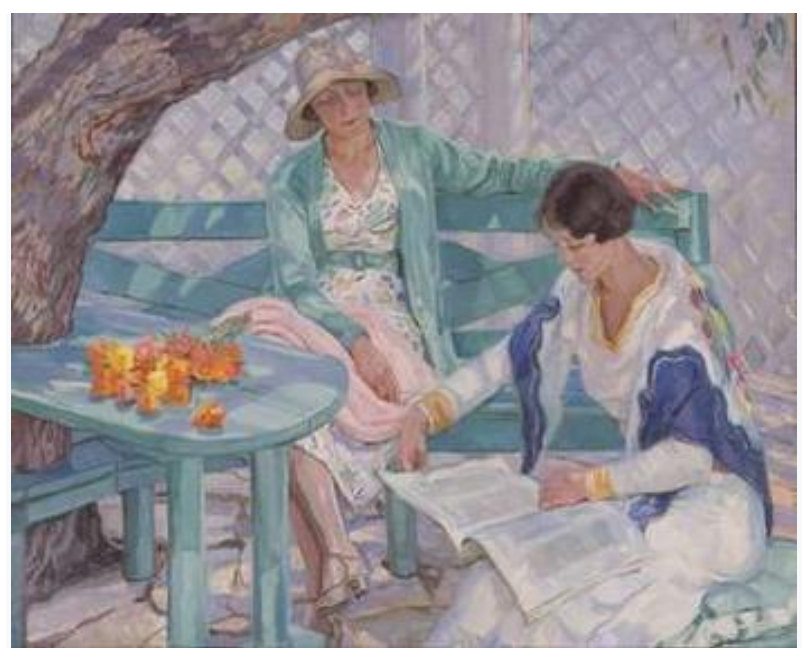

The Summer House, painted circa 1933, is one of Rix Nicholas's best known works, but the artist herself was ambivalent about it and never showed it publicly.

Characterising the modernist moment in Australian art - the period between the wars - is complex, ${ }_{1}^{[123]}$ as is understanding the position of individual artists within it. In France and North Africa in the 1910s, Rix Nicholas drew directly on impressionist ideas and techniques. In the 1920s, she had entertained Roy de Maistre, one of the first Australians to experiment with synchromism, and enthusiastically asked him to share more about his 'colour-music theory. ${ }^{102]}$ However, as she moved from urban to rural Australia, she did not continue to respond to radical modernist ideas. On one view, this represented a rejection of modernist themes and trends. ${ }^{[124]}$ Alternatively it can be read as Rix Nicholas's conscious decision to maintain her own crea- 
tive direction. As Petersen put it, "Rix Nicholas did not identify as a woman artist or as a modernist but simply as an artist working outside any movement or style" who "remained disinterested in the debates in Sydney over modern art trends". ${ }^{[125]}$ There was in any case, as art historian Jeanette Hoorn wryly observed, "no market for post-impressionist painting in outback New South Wales in the 1920s". [126]

Rix Nicholas sought to build on her existing success and often focussed on portraits. ${ }^{[126]}$ Women were frequently portrayed, enjoying active rural life (as in The Fair Musterer) and working the land ${ }^{[127]}$ as well as in domestic or family scenes (as in On The Hilltop). Several images, such as On the Hilltop and Spring Afternoon, Knockalong portray women caring for a young son in a rural setting. Her most "stereotypically feminine" ${ }^{[128]}$ work was The Summer House, which shows two of Rix Nicholas's friends with some freshly cut flowers, in a setting that, unlike most of her works of the period, screened out the surrounding landscape. It was a picture about which Rix Nicholas was never convinced and which she never publicly displayed. ${ }^{[128]}$ Yet it has become one of her best known works, its easy acceptance consistent with the way reviewers in the 1930s pigeon-holed her work in terms of conventional gender roles. ${ }^{[129]}$

Rix Nicholas had a number of exhibitions with some further critical success. Nevertheless, she became out of step with both the public, who bought few works at her last solo exhibition in 1947, and with some critics, who either rejected her work or criticised its lack of novelty. One critic, Adrian Lawler, observed:

Mrs Rix Nicholas is very gifted and she has her own individuality as an artist; but her personal outlook is not so much that of an artist with startling things to say ... as of a healthy fellowAustralian who loves the familiar beauty of our landscape and delights in representing it in all its splendour and virility. ${ }^{[122]}$

Another, considering a 1936 exhibition at the David Jones Gallery in Sydney, found the quality of her work uneven, and while he considered some to be strong, others were criticised as "nothing more than pretty and sentimental". ${ }^{[130]}$ Rix Nicholas's works remained insistent in their idealism about rural Australia, but following World War II, the country - and its art critics - had moved on. ${ }^{[131]}$ In 1945, The Sydney Morning Herald critic, lambasting Rix Nicholas's works as "crude in colour and poster-ish in presentation", concluded: "There is insufficient spiritual ma- terial to fill the canvases of Hilda Rix Nicholas ... The bravura, the boldness of these pictures is hardly in keeping with the actual knowledge displayed. A certain humility, a close attention to the organisation of detail, and less white mixed into the colours would help tremendously. "[132]

The antipathy between Rix Nicholas and prevailing trends in Australian art was mutual. She was appalled by the works of Russell Drysdale and William Dobell, describing the figures in their paintings as "more like victims of the German prison camps" than representations of Australian people. ${ }^{[133]}$ It seemed that the critics did not share her opinion: Dobell and Drysdale had each just won the Wynne Prize in successive years, ${ }^{[134]}$ and both would soon represent their country at the Venice Biennale..$^{[135]}$

A final trip to Europe took place in 1950. She set out to show her husband the sights of a Europe she knew well, and to find a teacher of sculpture for their son Rix. She was distressed by the standards of artistic practice she found, and instead discouraged Rix from any career in the arts at all. ${ }^{[136]}$

Following her last solo exhibition, a letter from Rix Nicholas to her son expressed despair in her artistic career and summarised the professional fate of her final years:

Not doing anything creative is nearly killing me. The trouble is that there is no one near me who cares whether I ever do any more work or not ... I feel the artist in me is dying and the dying is an agony... only one's self knows the craving and the best part in one is aching unsatisfied. ${ }^{[131]}$

By this time, her health was deteriorating, and her passion for art fading. ${ }^{[137]}$ Rix Nicholas did exhibit alongside her son in a group exhibition in Sydney, in 1954; she presented two oil paintings, while her son had the largest sculpture in the show, titled The Shearer. ${ }^{[138]}$ She died in Delegate on 3 August 1961..$^{[137][114]}$

\section{Legacy}

Gender was a recurring theme in Rix Nicholas's career, for better and for worse. Praise from a French art critic for her abilities was expressed by saying "[mademoiselle] Rix paints like a man!". ${ }^{[139]}$ An Australian critic was unsure what to say, admiring her composition but declaring her technique "strangely unfeminine", ${ }^{[140]}$ while another vitriolic review referred to the 
"pseudo-masculinity" of her works. ${ }^{[141]}$ Pigot considered that Rix Nicholas's career was ultimately penalised by her unwillingness to play by the male establishment's rules when she sought to stake out a woman's place in nationalist art in mid-twentieth century Australia. ${ }^{[142]}$ Sasha Grishin wrote that her "feminist tendencies and modernist touches were met with hostility". ${ }^{[143]}$ Art historian Catherine Speck had a different perspective on Rix Nicholas's post-World War I work, suggesting that it never subsequently attained the quality of her Paris output, because her first husband's death in the Great War drove her to create nationalist images of inconsistent quality. ${ }^{[144]}$ She suggested that Rix Nicholas's European works represented the modernist high point of the artist's career. ${ }^{[145]}$ Petersen agreed that "her tragic experiences during the war became integral to her artistic oeuvre and to her eventual concerns for national sentiment" but also thought that Rix Nicholas "continued to draw and paint with the same masterful sense of draughtsmanship, vigour and luminous paelette evident in her best work from Paris, Tangier and Sydney". ${ }^{[146]}$ In their reference work A Story of Australian Painting, Mary Eagle and John Jones considered Rix Nicholas, alongside Clarice Beckett, to be "the best woman artist to emerge from the artistic milieu of Melbourne in the decade of the First World War". ${ }^{[119]}$

Many of Rix Nicholas's works went into private collections for which records are limited. Many more were burned in a fire at the family property after her death in the 1960 s. $^{[147]}$ Despite having been welcomed to Australia as an "international art celebrity" in $1919,{ }^{[148]}$ her fortunes declined in the latter part of her career. However, the twenty-first century saw a renewed appreciation of her output. ${ }^{[149]}$ Her oeuvre is represented in most major Australia public galleries, including the Art Gallery of South Australia, ${ }_{1}^{[150]}$ the National Gallery of Australia, the National Gallery of Victoria and the Queensland Art Gallery, ${ }^{[151]}$ with many of the works (particularly those showing Moroccan subjects) purchased after the release of Hoorn's monograph. ${ }^{[152][153]}$ Other collections that have acquired her work include that of the Australian War Memorial. ${ }^{[92]}$ Internationally, Rix Nicholas is represented in the Galerie nationale du Jeu de Paume and Leicester Gallery, as well as by her works in the Luxembourg. ${ }^{[154]}$

There have been several posthumous solo exhibitions of Rix Nicholas's works: in 1971 at the Joseph Brown Gallery in Melbourne (established by artist Joseph Brown, donor of the Joseph Brown Collection) ${ }_{1}^{[155]}$ followed by a travelling exhibition in 1978, displayed at the Art Gallery of New South Wales, the Art Gallery of Ballarat and Macquarie Galleries. In the 1990s there were exhibitions at lan Potter Museum of Art in Melbourne and the Caspian Gallery in Sydney, ${ }^{[105]}$ and in 2010 at Bendigo Art Gallery. ${ }^{[156]}$ In 2013 an exhibition of her work was held at Canberra's National Portrait Gallery. ${ }^{[157]}$ The National Gallery of Australia in 2014 chose The Three Sisters, Blue Mountains as the painting it would seek to acquire through its Members Acquisition Fund appeal. ${ }^{[158]}$

\section{Notes}

1. $\uparrow$ Though born Emily Hilda Rix, neither published sources nor family correspondence normally use her first given name. The Australian Dictionary of Biography lists her as Emily Hilda Nicholas ${ }^{[1]}$ although no other source used that combination of names, nor did the artist herself.

2. $\uparrow$ The name is spelled as Brat by de Vries, ${ }^{[27]}$ and Braat by Pigot. ${ }^{[28]}$

3. $\uparrow$ While Hoorn's 2012 book suggested that Renoir had also visited Tangier, in a subsequent exchange between Hoorn and reviewer Roger Benjamin, it was clarified that Renoir had only travelled to Algiers in neighbouring Algeria. ${ }^{[35][36]}$

4. $\uparrow$ Also referred to as $A$ Tangier Market. See "General cable news". The Sydney Morning Herald. 16 December 1912. p. 10. Retrieved 10 February 2014.

5. $\uparrow$ Sources usually refer to Nicholas as a Major. He was promoted to Major two days before his death, but was a Captain at the time he met and married Rix. ${ }^{[69]}$

6. $\uparrow$ One 1919 report indicates that three works were purchased by the National Art Gallery, as it was then known. ${ }^{[82]}$

7. $\uparrow$ None of the cited sources record the outcome of this competition.

8. $\uparrow$ The Australian Dictionary of Biography entry on Rix Nicholas gives her son's name as Barrie Rix [Wright], while other sources refer only to Rix. ${ }^{[1]}$

\section{Citations}

1. Mitchell, Avenel (1988). "Nicholas, Emily Hilda (1884-1961)". Australian Dictionary of Biography. 11. Canberra: National Centre of Biography, Australian National University. ISBN 978-0-522-84380-4. Retrieved 17 March 2014.

2. $\uparrow$ Jump up to:2.0 2.1 Rix Nicholas, Hilda (2013). "The Three Sisters, Blue Mountains". National 
Gallery of Australia. Retrieved 12 December2013.

$\uparrow$ Pigot 2000, pp. 3-4.

$\uparrow$ Jump up to:4.0 4.1 4.2 4.3 Johnson 2012, p. 11.

$\uparrow$ Jump up to:5.0 5.1 Pigot 2000, p. 4.

$\uparrow$ Pigot 2000, pp. 4-5.

$\uparrow$ Pigot 2000, pp. 5-6.

$\uparrow$ Pigot 2000, p. 6.

$\uparrow$ Jump up to:9.0 9.1 9.2 Pigot 2000, p. 7.

$\uparrow$ Hoorn 2012, p. 18.

$\uparrow$ Johnson 2012, p. 37.

$\uparrow$ Johnson 2012, p. 21.

$\uparrow$ Pigot 2000, p. 8.

$\uparrow$ Jump up to:14.0 14.1 de Vries 2011, p. 127.

$\uparrow$ Johnson 2012, p. 12.

$\uparrow$ Hoorn 2012, p. 21.

$\uparrow$ Pigot 2000, p. 10.

$\uparrow$ Jump up to:18.0 18.1 Speck 2010, p. 65.

$\uparrow$ de Vries 2011, p. 130.

$\uparrow$ Pigot 2000, p. 12.

$\uparrow$ Pigot 2000, p. 14.

$\uparrow$ Pigot 2000, p. 16.

$\uparrow$ Pigot 2000, p. 17.

$\uparrow$ Hoorn 2012, p. 33.

$\uparrow$ Eagle \& Jones 1994, p. 120.

$\uparrow$ Pigot 2000, p. 19.

$\uparrow$ de Vries 2011, p. 133.

$\uparrow$ Jump up to:28.0 28.1 Pigot 2000, p. 18.

$\uparrow$ de Vries 2011, pp. 133-134.

$\uparrow$ "Australian artists abroad". The Sydney Morning Herald. 2 May 1911. p. 9.

Retrieved 8 February 2014.

$\uparrow$ Hoorn 2015, p. 22.

$\uparrow$ Taylor 2014, p. 11.

$\uparrow$ Pigot 1993, p. 3.

$\uparrow$ Hoorn 2012, p. 62.

$\uparrow$ Benjamin 2014.

$\uparrow$ Hoorn 2017.

$\uparrow$ Hoorn 2012, pp. 56, 63-64.

$\uparrow$ Jump up to:38.0 38.1 Hoorn 2012, pp. 99-103.

$\uparrow$ Hoorn 2008, p. 45.

$\uparrow$ Hoorn 2016, p. 135.

$\uparrow$ Hoorn 2012, p. 83.

$\uparrow$ Pigot 2000, p. 26.

$\uparrow$ Pigot 1993, p. 7.

$\uparrow$ Hoorn 2012, p. 193.

$\uparrow$ Hoorn 2012, p. 4.

$\uparrow$ Hoorn 2012, p. 128.

$\uparrow$ Hoorn 2016a, p. 97.

$\uparrow$ Hoorn 2012, p. 191.

$\uparrow$ Hoorn 2016, pp. 121-123.

$\uparrow$ Hoorn 2012, p. 9.

1. $\uparrow$ Hoorn, Jeanette (29 December 2012). "The

orient expressed". The Sydney Morning

Herald. Retrieved 25 June 2014.

52. $\uparrow$ Hoorn 2012.

53. $\uparrow$ "Melbourne artist sells picture to French Government". The Sunday Times. Sydney. 15 December 1912. p. 10. Retrieved 8 February 2014.
54. $\uparrow$ "The Old Salon". Examiner. Launceston, Tasmania. 30 April 1913. p. 5 Edition: Daily. Retrieved 8 February 2014.

55. $\uparrow$ "Women painters". The Sydney Morning Herald. 8 November 1919. p. 12. Retrieved 10 February 2014.

56. $\uparrow$ Hoorn 2012, p. 85.

57. $\uparrow$ Hoorn 2012, p. 3.

58. $\uparrow$ Speck 2010, p. 69.

59. $\uparrow$ Hoorn 2012, pp. 104-106.

60. $\uparrow$ Hoorn 2012, p. 88.

61. $\uparrow$ "Les Orientalistes". Journal des débats politiques et littéraires. 8 February 1913. p. 3. Retrieved 16 February 2014.

62. $\uparrow$ "Exposition E. Hilda Rix". La Chronique des arts et de la curiosité: supplément à la Gazette des beaux-arts. 28 December 1912. p. 281.

63. $\uparrow$ Hoorn 2012, pp. 115, 149.

64. $\uparrow$ Hoorn 2012, pp. 131-141.

65. $\uparrow$ Hoorn 2012, p. 187.

66. $\uparrow$ Pigot 2000, p. 27.

67. $\uparrow$ Speck 2010, p. 71.

68. $\uparrow$ Jump up to:68.0 68.1 Pigot 2000, p. 28.

69. $\uparrow$ "The Men Who Fell". Education Department's Record of War Service 19141919. Victorian Department of Education. 1921. p. 74. Retrieved 25 September 2014.

70. $\uparrow$ Pigot, John (2011) [1995]. "Hilda Rix Nicholas b. 1884 Ballarat, Victoria". Design and Art Australia Online. Retrieved 20 March2014.

71. $\uparrow$ Pigot 2000, pp. 28-29.

72. $\uparrow$ "Melbourne notes". The Sydney Morning Herald. 20 December 1916. p. 5. Retrieved 2 March 2014.

73. $\uparrow$ Rix Nicholas, Hilda (1980). "Study for the painting "Desolation"'. National Gallery of Australia. Retrieved 20 March 2014.

74. $\uparrow$ Speck 2004, p. 60.

75. $\uparrow$ Pigot 2000 , p. 30.

76. $\uparrow$ Speck 2004, p. 59.

77. $\uparrow$ Jump up to:77.0 77.1 "Work of Mrs Rix Nicholas". The Argus. Melbourne. 12 November 1918. p. 7. Retrieved 3 March 2014.

78. $\uparrow$ Pigot 2000, p. 31.

79. $\uparrow$ Pigot 2000, p. 33.

80. $\uparrow$ "The Women's Art Club exhibition". Punch. Melbourne. 21 November 1918. p. 37. Retrieved 3 March 2014.

81. $\uparrow$ Pigot 2000, p. 34.

82. $\uparrow$ Jump up to:82.0 82.1 "Virile pictures". Evening News. Sydney. 12 June 1919. p. 6. Retrieved 3 March 2014.

83. $\uparrow$ Jump up to:83.0 83.1 Pigot 2000 , p. 35.

84. $\uparrow$ Jump up to:84.0 84.1 Petersen 2014, p. 40.

85. $\uparrow$ Petersen 2014, p. 44. 
86. $\uparrow$ "Mrs Rix Nicholas". The Sydney Morning Herald. 16 September 1920. p. 6. Retrieved 3 March 2014.

87. $\uparrow$ Pigot 2000 , p. 37.

88. $\uparrow$ Hoorn 2012, p. 196.

89. $\uparrow$ Pigot 2000, pp. 59, 70-71.

90. $\uparrow$ Pigot 2000 , pp. 39-41.

91. $\uparrow$ Speck 2009, p. 279.

92. $\uparrow$ Jump up to:92.0 92.1 Pigot 2000, pp. 41-42, Plates

6, 16.

93. $\uparrow$ Speck 2009, p. 280.

94. $\uparrow$ Speck 2004, p. 80.

95. $\uparrow$ Pigot 2000, p. 42.

96. $\uparrow$ Jump up to:96.0 96.1 Pigot 2000, p. 44.

97. $\uparrow$ Pigot 2000, p. 46, Plates 20-22.

98. $\uparrow$ "A Virile Woman Painter". Sunday Times. Sydney: National Library of Australia. 5 August 1923. p. 21. Retrieved 5 March 2014. 99. $\uparrow$ de Vries 2011, p. 145.

100. $\uparrow$ "Olympic honors". Chronicle. Adelaide, SA. 19 July 1924. p. 46. Retrieved 5 March 2014.

101. $\uparrow$ Pigot 2000 , p. 49.

102. $\uparrow$ Jump up to:102.0 102.1 Pigot 2000, p. 50.

103. $\uparrow "$ "People Talked About. Gifted Victorian artist". The World's News. Sydney: National Library of Australia. 28 February 1925. p. 11.

Retrieved 10 March 2014.

104. $\uparrow$ de Vries 2011, p. 151.

105. $\uparrow$ Jump up to:105.0 105.1 Pigot 2000, p. 75.

106. $\uparrow$ Pigot 2000 , p. 45.

107. $\uparrow$ de Vries 2011, p. 147.

108. $\uparrow$ Jump up to:108.0 108.1 Pigot 2000, p. 76.

109. $\uparrow$ "Australian woman artist". Newcastle Morning Herald \& Miners' Advocate. NSW: National Library of Australia. 5 December 1925. p. 14. Retrieved 10 March 2014.

110. $\uparrow$ Jump up to: 110.0110 .1 Pigot 2000, p. 55.

111. $\uparrow$ Jump up to:111.0 111.1 111.2 111.3 Rix Nicholas, Hilda (2008). "Les fleurs dédaignées". National Gallery of Australia. Retrieved 22 March2014.

112. $\uparrow$ "Mrs Rix Nicholas". The Sydney Morning Herald. 4 June 1927. p. 16. Retrieved 22 March 2014.

113. $\uparrow$ Pigot 2000, pp. 52-55.

114. $\uparrow$ Jump up to:114.0 114.1 Pigot 2000, p. 74.

115. $\uparrow$ "Australian art worthily represented in Parisian exhibitions". Sunday Times. Sydney. 13 June 1926. p. 20. Retrieved 10 March2014.

116. $\uparrow$ "Australians abroad". Sunday Times. Sydney. 8 August 1926. p. 20. Retrieved 10 March 2014.

117. $\uparrow$ Johnson 2012, pp. 29-30.

118. $\uparrow$ de Vries 2011, p. 152.

119. $\uparrow$ Jump up to: 119.0 119.1 Eagle \& Jones 1994, p. 123.

120. $\uparrow$ Moore, William (29 January 1927). "Art and Artists". The Brisbane Courier. Qld. p. 20. Retrieved 29 March 2014.

121. $\uparrow$ Pigot 2000, p. 60.
122. $\uparrow$ Jump up to:122.0 122.1 122.2 Johnson 2012, p. 30.

123. $\uparrow$ Smith 2002, pp. 23-42.

124. $\uparrow$ Cooper-Lavery 2010, p. 22.

125. $\uparrow$ Petersen 2014, p. 48, 56.

126. $\uparrow$ Jump up to:126.0 126.1 Hoorn 2012, p. 199.

127. $\uparrow$ Cooper-Lavery 2010, p. 8.

128. $\uparrow$ Jump up to:128.0 128.1 Pigot 2000, pp. 62-63.

129. $\uparrow$ Pigot 2000, pp. 63-64.

130. $\uparrow$ "Oil paintings". The Sydney Morning Herald. 15 June 1936. p. 5. Retrieved 25 February 2014.

131. $\uparrow$ Jump up to:131.0 131.1 Pigot 2000, p. 71.

132. $\uparrow$ "Woman painter's work". The Sydney Morning Herald. 6 February 1945. p. 7. Retrieved 22 March 2014.

133. $\uparrow$ Pigot 2000, p. 67.

134. $\uparrow$ "Wynne Prize - Explore past winners and finalists". Art Gallery of New South Wales. Retrieved 16 February 2014.

135. $\uparrow$ "Past Representation". Projects -> Venice Biennale. Australia Council for the Arts. Archived from the original on 17 March 2014. Retrieved 17 March 2014.

136. $\uparrow$ Pigot 2000, pp. 71-72.

137. $\uparrow$ Jump up to:137.0 137.1 Johnson 2012, p. 33.

138. $\uparrow$ "Mother and son exhibit country art". The Sydney Morning Herald. 8 October 1954. p. 9. Retrieved 25 February 2014.

139. $\uparrow$ de Vries 2011, p. 125.

140. $\uparrow$ Hoorn 2012, p. 188.

141. $\uparrow$ Cooper-Lavery 2010, p. 18.

142. $\uparrow$ Pigot 2000, pp. $1-2$.

143. $\uparrow$ Grishin 2013, p. 169.

144. $\uparrow$ Speck, Catherine (2013). "The 'Frontier' Speaks Back". PORTAL Journal of Multidisciplinary International Studies 10 (2): 15. Retrieved 27 March 2014.

145. $\uparrow$ Speck 2010, p. 72.

146. $\uparrow$ Petersen 2014 , pp. 40,56 .

147. $\uparrow$ Hoorn 2012, p. 192.

148. $\uparrow$ Taylor 2014, p. 40.

149. $\uparrow$ de Vries 2011, p. 155.

150. $\uparrow$ Rix Nicholas, Hilda (1996). "Australian paintings: Monaro pioneer". Art Gallery of South Australia. Retrieved 14 March 2014.

151. $\uparrow$ Rix Nicholas, Hilda (1971). "Collection search: The fair musterer 1935". Queensland Art Gallery. Retrieved 15 March 2014.

152. $\uparrow " H i l d a$ Rix Nicholas, Moroccan Loggia 1912-1914". National Gallery of Australia. Retrieved 27 September 2019.

153. $\uparrow$ "Hilda Rix Nicholas". National Gallery of Victoria Collection online. Retrieved 27 September 2019.

154. $\uparrow$ Ambrus 1984, p. 189.

155. $\uparrow$ Vaughan, Gerard (4 September 2009). "Joseph Brown: Mentor and collector who made a difference". The Australian. Retrieved 20 March 2014.

156. $\uparrow$ Cooper-Lavery 2010. 
157. $\uparrow$ Pryor, Sally (30 May 2013). "World comes to life on artist's broad canvas". The Canberra Times. Retrieved 10 February 2014.

158. $\uparrow$ "Support us". Artonline 177. February 2014. Retrieved 23 March 2014.

\section{Sources}

- $\quad$ Ambrus, Caroline (1984). The Ladies' Picture Show: Sources on a century of Australian women artists. Sydney: Hale \& Iremonger. ISBN 9780-86806-160-3.

- Benjamin, Roger (2014). "Review of 'Hilda Rix Nicholas and Elsie Rix's Moroccan Idyll: Art and Orientalism'". Australian and New Zealand Journal of Art 14 (2): 222-225.

- Cooper-Lavery, Tracy (2010). "The man for the job". In Tracy Cooper-Lavery (ed.). Hilda Rix Nicholas. The man for the job. Bendigo: Bendigo Art Gallery. pp. 6-23. ISBN 978-0949215581.

- de Vries, Susanna (2011). Trailblazers: Caroline Chisholm to Quentin Bryce. Brisbane: Pirgos Press. ISBN 978-0-9806216-1-7.

- Eagle, Mary; Jones, John (1994). A Story of Australian Painting. Chippendale, NSW: Macmillan Australia. ISBN 978-0-7329-0778-5.

- Grishin, Sasha (2013). Australian Art: A History. Carlton, Victoria: The Miegunyah Press. ISBN 9780522856521.

- Hoorn, Jeanette (2008). "Letters from Tangiers: the creative partnership between Elsie and Hilda Rix in Morocco". In Robert Dixon and Veronica Kelly (ed.). Impact of the Modern: Vernacular Modernities in Australia 1870s-1960s. Sydney: Sydney University Press. pp. 38-51. ISBN 9781-920898-89-2.

- Hoorn, Jeanette (2012). Hilda Rix Nicholas and Elsie Rix's Moroccan Idyll : Art and Orientalism. Carlton, Victoria: The Miegunyah Press. ISBN 978-0-522-85101-4.

- Hoorn, Jeanette (2015). "Women and Men and Public Space, Hilda Rix Nicholas and Henri Matisse in Morocco". Hecate 40 (2): 7-23.
- Hoorn, Jeanette (2016). "Painting Portraits in Private". Third Text 30 (1): 117-137.

- Hoorn, Jeanette (2016a). "Feminising Orientalism, The Art of Hilda Rix Nicholas". Hecate 42: 92-105.

- Hoorn, Jeanette (2017). "Rejoinder to review of 'Hilda Rix Nicholas and Elsie Rix's Moroccan Idyll: Art and Orientalism'". Australian and New Zealand Journal of Art 17 (1): 126-128.

- Johnson, Karen (2012). In Search of Beauty: Hilda Rix Nicholas' Sketchbook Art. Canberra: National Library of Australia. ISBN 978-0-64227752-7.

- Petersen, Julie (2014). "The return of the cosmopolitan artist". In Julie Petersen (ed.). Une Australienne: Hilda Rix Nicholas in Paris, Tangier and Sydney. Sydney: Mosman Art Gallery. pp. 39-58. ISBN 978-09808466-5-2.

- Pigot, John (2000). Hilda Rix Nicholas: Her Life and Art. Carlton South, Victoria: The Miegunyah Press. ISBN 978-0-522-84890-8.

- Pigot, John (1993). Capturing the Orient: Hilda Rix Nicholas and Ethel Carrick in The East. Waverley, Victoria: Waverley City Gallery.

- Smith, Terry (2002). Transformations in Australian Art. The Twentieth Century - Modernism and Aboriginality. St Leonards, NSW: Craftsman House. ISBN 1-877004-14-6.

- Speck, Catherine (2004). Painting ghosts: Australian women artists in wartime. Melbourne: Craftsman House. ISBN 1-877004-22-7.

- Speck, Catherine (2009). "The Australian War Museum, Women Artists and the National Memory of the First World War". When the Soldiers Return: November 2007 Conference Proceedings: 277-290.

- Speck, Catherine (2010). "The brilliant early years". In Tracy Cooper-Lavery (ed.). Hilda Rix Nicholas. The man for the job. Bendigo: Bendigo Art Gallery. pp. 65-73. ISBN 978-0949215581.

- Taylor, Elena (2014). "An Australian in Paris". In Julie Petersen (ed.). Une Australienne: Hilda Rix Nicholas in Paris, Tangier and Sydney. Sydney: Mosman Art Gallery. pp. 9-21. ISBN 97809808466-5-2. 